\title{
Flow Sitometri ile Çok Yıllık Buğdaygil Yem Bitkisi Genetik Kaynaklarının Karakterizasyonu
}

\author{
*Gülsemin SAVAŞ TUNA ${ }^{1}$ Hüseyin KELEŞ² Damla GÖÇMEN² Vesile GÜLERYÜZ² \\ Illker NiZAM ${ }^{2}$ Evren CABi ${ }^{3}$ Ayşe YAZICI $^{4}$ Şerafettin ÇAKAL ${ }^{4}$ Metin TUNA ${ }^{2}$
}

\author{
${ }^{1}$ Ebru Nayim Fen Lisesi, Tekirdağ \\ ${ }^{2}$ Namık Kemal Üniversitesi, Ziraat Fakültesi, Tarla Bitkileri Bölümü, Tekirdağ \\ ${ }^{3}$ Namık Kemal Üniversitesi, Fen Fakültesi, Biyoloji Bölümü, Tekirdağ \\ ${ }^{4}$ Doğu Anadolu Tarımsal Araştırma Enstitüsü Müdürlüğü, Erzurum \\ *Sorumlu yazar e-posta (Corresponding author e-mail): glsvs@yahoo.com
}

\section{Öz}

Çok yıllık buğdaygil yem bitkisi türlerinin morfolojik olarak birbirlerine çok benzemeleri, aralarında kolayca melezlenerek hibrit türler oluşturabilmeleri ve doğal varyasyon sebebiyle teşhislerinde ciddi sorunlar yaşanmaktadır. Buna ilave olarak bu türlerde polyploidi çok yaygındır ve aynı türün dahi farklı kromozom sayılarına sahip formları mevcuttur. Bundan dolayı çok yıllık buğdaygil türlerine ait genetik kaynakların bilimsel araştırma ve ıslah çalışmalarında kullanılmadan önce tür teşhislerinin doğru bir şekilde yapılarak ploidi düzeylerinin belirlenmesi zorunludur. Aksi taktirde yapılacak olan melezlemelerde ortaya çıkabilecek genetik uyuşmazlık ve kısırlık gibi sorunlar araştırıcıların zaten kıt olan emek, zaman ve maddi kaynaklarının heba olmasına sebep olmaktadır. Bu çalışmada, ıslah programlarında kullanmak amacıyla Doğu Anadolu Bölgesi dağlık bölgelerinden toplanmış olan 169 buğdaygil yem bitkisi popülasyonunun (Festuca sp., Koeleria sp. ve Agropyron sp.) çekirdek DNA içerikleri flow sitometri yöntemi ile ilk defa belirlenmiş ve popülasyonların ploidi düzeyi ile safiyetlerinin belirlenmesinde kullanılmıştır. Yapılan çekirdek DNA analizi sonuçlarına göre Festuca popülasyonlarında ploidy düzeyi diploid ile octoploid $(2 n=14,28$, 42, ve 56$)$ arasında değişirken Koeleria popülasyonlarında diploid $(2 n=14)$ ile tetraploid $(2 n=28)$ arasında değiştiği belirlenmiştir. Bununla birlikte bazı popülasyonların ise saf olmayıp farklı ploidy düzeyine sahip bitkilerden oluştuğu saptanmıştır. Çalışmada incelenen tüm Agropyron popülasyonlarının ise diploid $(2 n=14)$ olduğu belirlenmiştir. Çalışmada kullanılan tüm popülasyonlar çekirdek DNA analiz sonuçlarınında yardımıyla taksonomik olarak teşhis edilmiş ve isimlendirilmiştir.

Anahtar Kelimeler: Festuca sp., Koeleria sp., Agropyron sp., flow sitometri, genetik kaynak

\section{Characterisation of Genetic Resources of Perennial Forage Grasses by Using Flow Cytometry}

\begin{abstract}
Taxonomic identification of perennial forage grasses is a difficult task due to their morphological similarities, ability to form interspecific hybrids by crossbreeding and natural variation. Additionally, polyploidy is very common in those species and there are individuals with different chromosome numbers within the same species. Therefore, it is necessary to identify plants taxonomically and determine their ploidy levels before using them in basic scientific research and plant breeding projects. Otherwise, the problems such as genetic incompatibility and sterility that may occur during the crossings can cause waste of limited resources of the researchers such as labour, time and money. In this study, nuclear DNA contents of 169 populations of the forage grasses (Festuca sp, Koeleria sp and Agropyron sp) collected from mountainous areas of Eastern Anatolia Region to use in breeding programmes were determined for the first time using flow cytometry and the information obtained from nuclear DNA content analysis was used to determine the ploidy levels and purity of the populations. According to the results of the study, ploidy levels of Festuca populations varied between diploid and octoploid $(2 n=14,28,42$, and 56$)$ while ploidy levels varied between diploid $(2 n=14)$ and tetraploid $(2 n=28)$ in Koeleria populations. In addition, some populations were not pure and included plants with different ploidy levels. All Agropyron populations analysed in the study were diploid $(2 n=14)$. All populations analysed in the study were taxonomically identified and named with the help of nuclear DNA analysis.
\end{abstract}

Keywords: Festuca sp., Koeleria sp., Agropyron sp., flow cytometry, genetic resources 


\section{Giriş}

B uğdaygil yem bitkisi türlerinin taksonomisi oldukça karmaşık olup türlerin teşhisi ve sınıflandırılması ciddi bir uzmanlık gerektirmektedir. Aynı cins içerisinde yer alan buğdaygil türlerinin birbirlerine çok benzemeleri, aralarında kolayca melezlenerek hibrit türler oluşturabilmeleri, poliploidinin yaygın olması ve doğal varyasyon sebebiyle bu türlerin teşhislerinde ciddi sorunlar yaşanmaktadır. Bu nedenlerle buğdaygillere ait genetik kaynakların bilimsel araştırmalarda kullanılmadan önce tür teşhislerinin doğru bir şekilde yapılarak ploidi düzeylerinin belirlenmesi zorunludur. Aksi taktirde çeşitli sorunlar (genetik uyuşmazlık, kısırlık, zaman ve emek kaybı) yaşanmaktadır. Bitkilerin ploidi düzeyi geleneksel olarak yavaş ve çok fazla iş gücü gerektiren feulgen veya asetokarmin ile boyanmış kök ucu dokularından hazırlanmış preparatlarda mitoz kromozomlarını ışık mikroskobu ile sayarak belirlenmektedir (Karp, 1991). Ancak, yöntem genetik kaynak kolleksiyonlarında olduğu gibi çok sayıda bitki örneğinin analiz edilmesinin gerektiği durumlarda ploidi düzeyi belirlemede pratik ve kullanışlı değildir. Buna ilave olarak, kromozomları küçük ve ploidi düzeyi yüksek olan türlerde bu yöntem ile ploidi analizi oldukça zahmetlidir ve çoğunlukla da genetik kaynakların yanlış sınıflandırılmasına neden olmaktadır (Brummer ve ark., 1999). Bitkilerin sahip olduğu tüm kromozomlar hücre çekirdeğinde bulunduğundan, çekirdek DNA miktarı ile ploidi düzeyi arasında sıkı bir doğrusal ilişki vardır (Lu et al. 1998). Bu nedenle çekirdek DNA içeriği esasına göre ploidi analizi giderek yaygınlaşmaktadır. Önceleri bitkilerde çekirdek DNA miktarları feulgen mikrospektrofotometri ile belirlenmekteydi (Bennett and Smith 1976). Ancak, son yıllarda, kolaylığı, hızı ve hassasiyetinden dolayı flow sitometri ploidi analizlerinde tercih edilen metot olmuş ve başarıyla kullanılmaktadır (Rayburn et al. 1989; Heslop-Harrison 1995, Tuna ve ark. 2001, 2005, 2006). Bir bitki hücresindeki DNA miktarı "C" harfi ile pikogram cinsinden belirtilir. $\mathrm{C}$ değeri haploid genom; $2 \mathrm{C}$ değeri ise diploid somatik genomun DNA miktarını ifade etmektedir. Bitkilerin çekirdek DNA' larına ait C değerleri 0.1 pg ile 125 pg arasında değişmektedir. Pikogram cinsinden belirlenen DNA miktarları nükleotid baz çiftine (1pg = $980 \mathrm{Mbp}$ ) dönüştürülebilmektedir (Bennett and Leitch, 1995). Genom başına çekirdek DNA miktarı hem tek bir bitkinin hücreleri arasında hem de aynı türün farklı bireyleri arasında değişmeyerek sabit kalmakta ve bu yüzden de türlere özel olmaktadır. Çekirdek DNA miktarlarının türlere özel olması, çekirdek DNA' sı değerlerini sitotaksonomi ve evrim çalışmaları için vazgeçilmez bir temel bilgi yapmaktadır (Bennett and Leitch 1995). Rees and Walters (1965) feulgen metodu ile belirlenmiş çekirdek DNA miktarlarından yola çıkarak hexaploid olan ekmeklik buğdayın orjinlendiği yabani buğday türlerini belirlemiş ve evrimini incelemiştir. Ohri (1998) bir cins içerisinde aynı kromozom sayısına sahip çok sayıda türün bulunduğu durumlar, varsa türler arasındaki çekirdek DNA içeriği farklılıklarının türlerin teşhisi ve sınıflandırılmalarında çok etkili olduğunu bildirmiştir. Bu çalışmada; ıslah programlarında kullanmak amacıyla ülkemizin Doğu Anadolu Bölgesi doğal florasından toplanmış olan 3 buğdaygil yem bitkisi cinsine (Festuca L., Koeleria Pers. ve Agropyron Gaertn.) ait 169 adet doğal popülasyonun çekirdek DNA içerikleri ile ploidi düzeylerini belirlemek ve elde edilen verileri kullanarak türleri teşhis etmek amaçlanmıştır.

\section{Materyal ve Yöntem}

Bu çalışmada; Doğu Anadolu Tarımsal Araştırma Enstitüsü tarafından ülkemizin Doğu Anadolu Bölgesi doğal florasından toplanmış olan 3 buğdaygil yem bitkisi cinsine ait genetik kaynak koleksiyonlarını oluşturan 169 popülasyon (131 Festuca, 24 Koeleria, ve 14 Agropyron) materyal olarak kullanılmıştır.

\section{Tohumların Ekilmesi ve Yetiştirilmesi}

Popülasyonlardan her birine ait tohumlar 3:1 oranında steril torf ve perlit kullanılarak viyollere ekilmiştir. Plastik sera içerisinde yetiştirilen fideler her popülasyondan 7 bitki olacak şekilde, aralıklı olarak $(100 \times 100 \mathrm{~cm})$ tarlaya şaşırtılmıştır.

\section{Çekirdek DNA Analizi}

Çekirdek DNA analizleri Tarla bitkileri Ana Bilim Dalı, Bitki Genetiği ve Sitogenetiği Laboratuarında bulunan PARTEC marka Flow sitometri cihazı kullanılarak yapılmıştır. Analizler Agropyron cristatum hariç her popülasyon için 5 tek bitki üzerinde ayrı ayrı yapılmış ve popülasyon ortalaması hesaplanmıştır.

Agropyron cristatumda ise büyük bir varyasyon gözlenmemesi sebebiyle her popülasyondan 3 bitki analiz edilmiştir. 
Analizlerde Agropyron için çavdar, Festuca ve Koeleria için adi fiğ bitkisi standart olarak kullanılmıştır. Analizlerde PARTEC firmasının hazır kitleri kullanılmış ve üretici firmanın protokolü takip edilmiş olup prosedür kısaca aşağıdaki gibidir. Yaklaşık olarak $0.5 \mathrm{~cm}^{2}$ büyüklüğünde taze yaprak dokusu petri kabına alınır ve üzerine $500 \mu \mathrm{l}$ Exraction Buffer ilave edilir. Yaprak dokusu keskin jilet ile küçük parçalara ayrılana kadar (30-60 saniye) parçalanır. Hazırlanan örnek petri kabı içerisinde hafifçe çalkalanır (10-15 saniye). Çalkalama işleminden sonra 40 saniye kadar petri kabında bekletilen örnek Partec marka $30 \mu \mathrm{m}$ CellTrics filtre ile süzülerek tüp içerisine transfer edilir. Tüp içerisine daha önce hazırlanmış $2 \mathrm{ml}$ staining solüsyonu ilave edilir. Hazırlanan örnek ışıksız bir ortamda 30-60 dakika inkübe edilir. Bu sürenin sonunda örnekler flow sitometri cihazı kullanılarak analiz edilir.

\section{Staining Solüsyonun Hazırlanması}

Her örnek için; $2 \mathrm{ml}$ Staining Buffer, $6 \mu \mathrm{l}$ RNAse stok solüsyon ve $12 \mu \mathrm{l} \mathrm{PI}$ (Propidium lodide) stok solüsyonu karıştırılarak staining solüsyonu hazırlanır.

\section{Çekirdek DNA İçeriğinin Hesaplanması}

Bir örneğin mutlak çekirdek DNA içeriği, örnek ile seçilen standardın $\mathrm{G} 1$ piklerinin florasan yoğunluklarına ait değerler kullanılarak aşağıdaki formül aracılığıyla pikogram olarak hesaplanır (Formül 1).

\section{İstatistiksel Analiz}

Her cinse ait popülasyonların çekirdek DNA ortalamaları confidence intervalları kullanarak kendi aralarında kıyaslanmıştır.

\section{Mitoz Kromozomlarının Sayılması}

Popülasyonların çekirdek DNA içeriği ile kromozom sayılarını ilişkilendirmek amacıyla her cins içerisinde çekirdek DNA içeriği bakımından farklılık gösteren popülasyonları temsilen en az bir bitkinin mitoz kromozomları sayılmıştır. Kromozom sayımları kök ucu meristem dokuları kullanılarak Feulgen metoduna göre hazırlanmış olan preparatların ışık mikroskobu altında incelenmesiyle yapılmıştır.

\section{Taksonomik Teşhisler}

Teşhislerde 2012 bahar aylarında deneme alanına dikilen bitkiler kullanılmıştır. Herbaryum materyali haline getirilen bitkiler, Türkiye ve Doğu Ege Adaları Florasında (Davis 1985) verilen ilgili cins anahtarları kullanılarak teşhis edilmiştir.

\section{Bulgular ve Tartışma}

Bu çalışma, ülkemiz florasından toplanmış olan Agropyron, Koaleria ve Festuca türleri üzerinde ilk kez yapılan çekirdek DNA analizi sonuçlarını içermektedir. Flow sitometri analizleri sonucunda; $A$. cristatum popülasyonlarının ortalama çekirdek DNA içeriklerinin $12.97 \mathrm{pg} / 2 \mathrm{C}$ ile $13.01 \mathrm{pg} / 2 \mathrm{C}$ arasında değiştiği gözlenmiştir (Şekil 1). Yapılan analizlerde popülasyonların ortalamaları arasındaki farkın istatistiksel açıdan

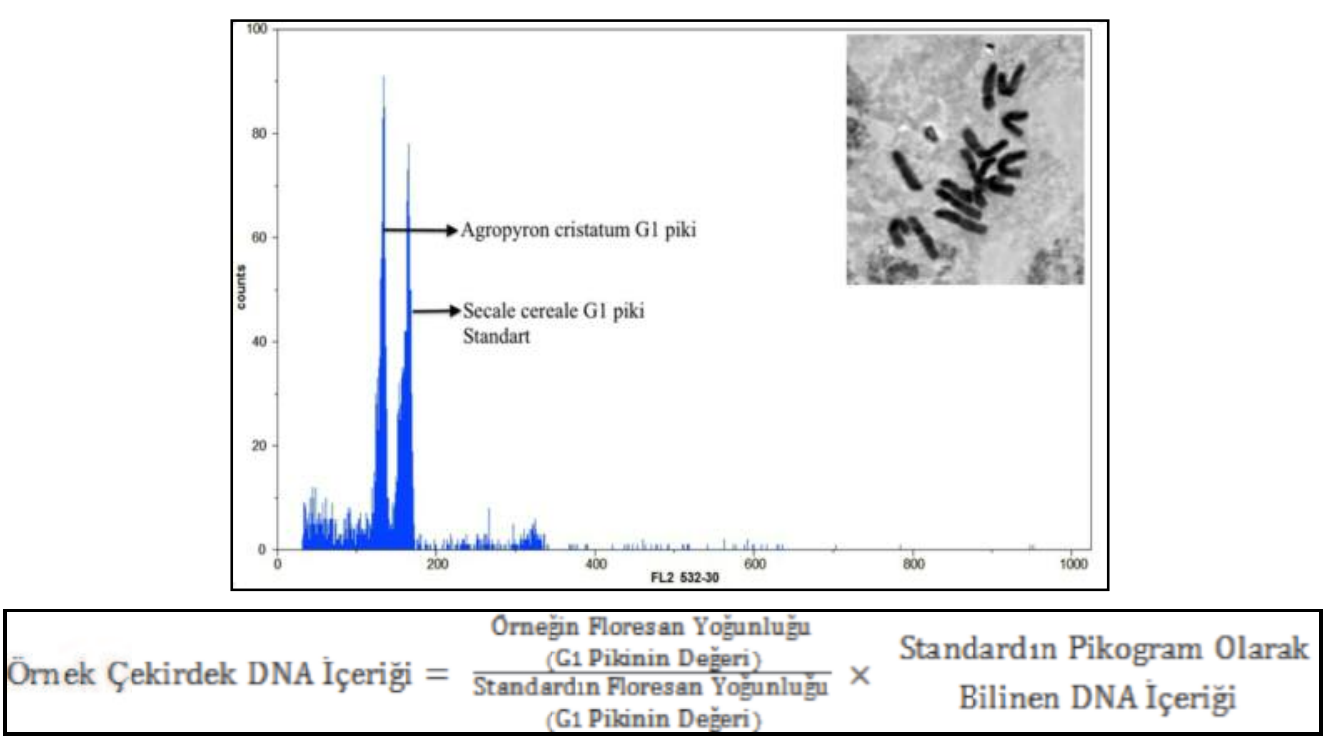

Şekil 1.a) Çekirdek DNA içeriğinin hesaplanması b) Agropyron cristatum ile standart bitkiye (Secale cereale) ait G1 piklerinin bir birlerine göre pozisyonları ve A. cristatum'un mitoz kromozomlarının görünüşü

Figure 1. a) Calculation of nucleus DNA b) Positions of Agropyron cristatum and G1 peaks of referance plant (Secale cereale) and view of mitosis chrosomes of $A$. Cristatum 
önemsiz olduğu saptanmıştır. Bu sonuç analiz edilen tüm Agropyron popülasyonlarının tek bir türe ait olduğunu işaret etmektedir. Populasyonların çekirdek DNA içeriklerini ploidy düzeyleri ile ilişkilendirmek için koleksiyonu oluşturan bazı $A$. cristatum bitkilerinin kromozomları sayılmış ve tüm bitkilerin 14 kromozoma $(2 n=14)$ sahip olduklarını ve dolayısıyla tüm $A$. cristatum populasyonlarının diploid olduğu belirlenmiştir (Şekil 1). Çalışmada elde edilen sonuçların, Vogel et al. (1999)'nın yapmış olduğu çalışmadaki sonuçlar (13.93) ile oldukça benzer olduğu gözlenmiştir. Aradaki küçük farklıığın çalışmalarda kullanılan standart bitkiden kaynaklandığı düşünülmektedir. Koeleria popülasyonlarının ortalama çekirdek DNA içeriklerinin ise $4.81 \mathrm{pg} / 2 \mathrm{C}$ ile $9.40 \mathrm{pg} / 2 \mathrm{C}$ arasında değiştiği gözlenmiştir. Yapılan istatistiksel analiz sonucu popülasyonların çekirdek DNA ortalamaları arasındaki farkın istatistiksel açıdan önemli olduğu saptanmış ve Koeleria popülasyonlarının 4 farklı gruba ayrıldığı gözlenmiştir. 1. grupta (grup A) ortalama çekirdek DNA içeriği $4.86 \mathrm{pg} / 2 \mathrm{C}$ olan tek bir popülasyon yer almaktadır. 2. grupta (grup B) ortalama çekirdek DNA içeriği $5.14 \mathrm{pg} / 2 \mathrm{C}$ olan yine tek bir popülasyon yer almaktadır. 3. grupta ortalama çekirdek DNA içeriği $5.41 \mathrm{pg} / 2 \mathrm{C}$ ile $5.57 \mathrm{pg} / 2 \mathrm{C}$ olan 20 popülasyon yer almaktadır. 4 . grupta ise ortalama çekirdek DNA içerikleri $9.44 \mathrm{pg} / 2 \mathrm{C}$ ile $9.47 \mathrm{pg} / 2 \mathrm{C}$ olan 2 popülasyon yer almaktadır. Yapılan kromozom sayımlarında 1., 2. ve 3. gruptaki bitkilerin diploid $(2 n=14), 4$. gruptaki bitkilerin ise tetraploid $(2 n=28)$ olduğu belirlenmiştir (Şekil 2). Yapılan taksonomik değerlendirmede diploid popülasyonlar $K$. cristata, tetraploidler ise $K$. nitidula olarak teşhis edilmişlerdir. Çalışmada elde edilen sonuçlar
Pecinka et al. (2006)'ın Avrupa'nın orta bölgelerinden elde ettikleri Koeleria taksonları üzerinde yaptıkları çalışmadan elde ettikleri sonuçlar ile büyük benzerlik göstermektedir. Pecinka ve arkadaşları yaptıkları çalışmada $2 \mathrm{C}$ çekirdek DNA içeriği 4.85-5.20 pg arasında değişen 3 diploid, ortalama $2 \mathrm{C}$ çekirdek DNA içeriği $9.31 \mathrm{pg}$ olan 1 tetraploid, ortalama $2 \mathrm{C}$ çekirdek DNA içeriği 22.89 pg olan 4 decaploid ve ortalama 2C çekirdek DNA içeriği 29.23 pg olan 1 dodecaploid tür bulunduğunu saptamışlardır. Araştırıcılar diploid türleri $K$. glauca, K. macrantha, K. pseudoglauca olarak, tetraploid türü K. majoriflora, olarak, decaploid türü $K$. pyramidata ve dodecaploid türü $K$. tristis olarak teşhis etmişlerdir.

Çekirdek DNA içeriklerinin bir birine çok benzer olmasına rağmen çalışmalar arasındaki türlerin farklı türler olmaları ve Erzurum bölgesinde decaploid ile dodecaploid türlere rastlanmamasının bölgeler arasındaki flora farklıı̆ından kaynaklanmış olabileceği düşünülmektedir.

Yapılan analizlerde; Festuca popülasyonlarının ortalama çekirdek DNA içeriklerinin $4.51 \mathrm{pg} / 2 \mathrm{C}$ ile $15.03 \mathrm{pg} / 2 \mathrm{C}$ arasında değiştiği gözlenmiştir. İstatistiksel analiz sonucunda popülasyonların çekirdek DNA ortalamaları arasındaki farkın istatistiksel açıdan önemli olduğu saptanmış ve Festuca popülasyonlarının 9 farklı gruba ayrıldığı gözlenmiştir. Birinci (grup A) ve ikinci grupta (grup B) yer alan 72 popülasyonun ortalama çekirdek DNA içerikleri bir birine oldukça yakın olup, 4.51 $\mathrm{pg} / 2 \mathrm{C}$ ile $4.80 \mathrm{pg} / 2 \mathrm{C}$ arasında değişmektedir. Bu iki grubun ortalama çekirdek DNA içeriklerinin bir birine yakın olması grupların birbirine çok benzer
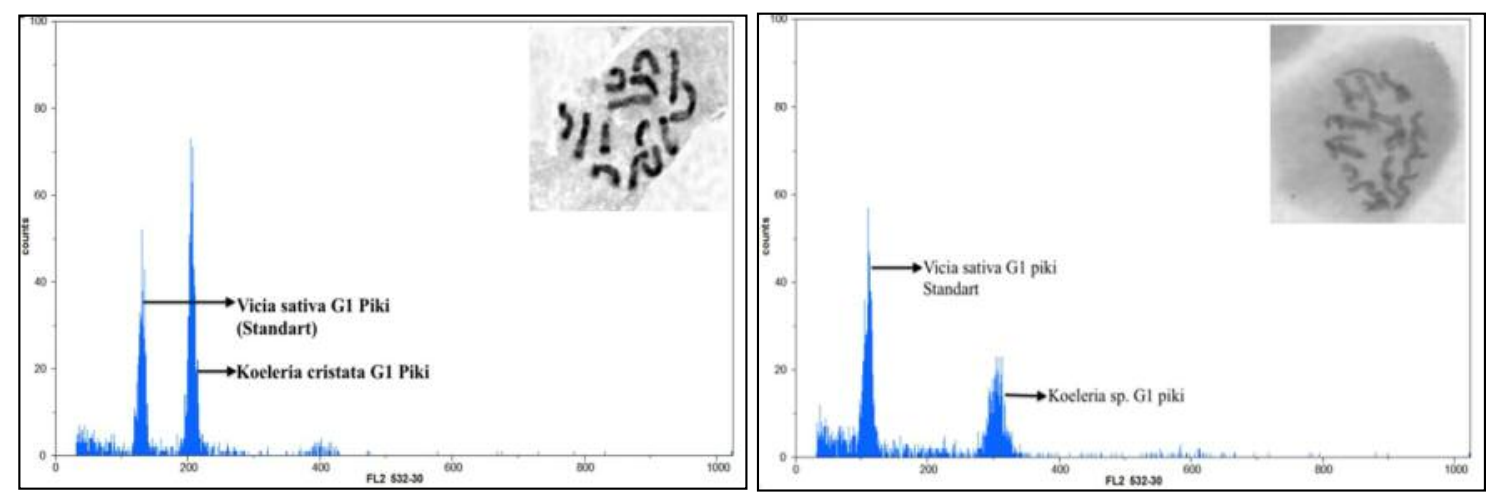

Şekil 2. Diploid (sol) ve tetraploid (sağ) Koeleria bitkileri ile standart bitkiye ait (Vicia sativa) ait G1 piklerinin bir birlerine göre pozisyonları, ve diploid ve tetraploid Koeleria bitkilerinin mitoz kromozomlarının görünüşü

Figure 2. Positions of diploid (left) and tetraploid (right) Koeleria plants referance plant (Vicia sativa) G1 peaks and the view of mitosis chrosomes of diploid and tetraploid Koeleria plants 

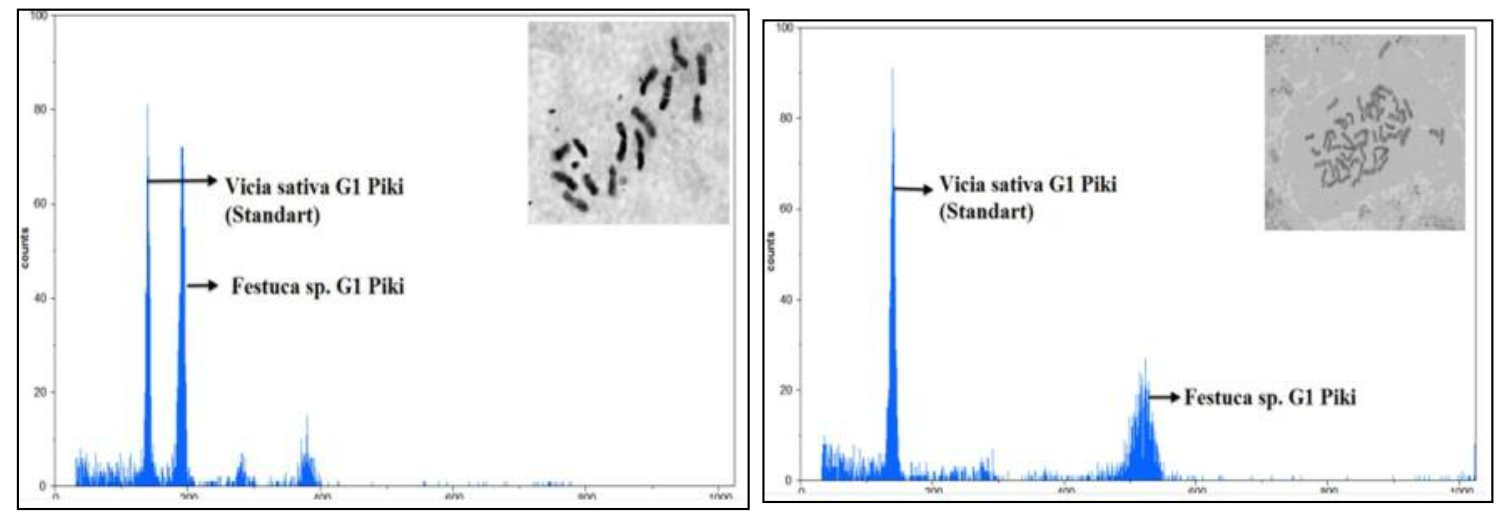

Şekil 3. Diploid (sol) ve octaploid (sağ) Festuca bitkileri ile standart bitkiye ait (Vicia sativa) ait G1 piklerinin bir birlerine göre pozisyonları, ve Festuca bitkilerinin mitoz kromozomlarının görünüşü

Figure 3. Positions of diploid (left) and octoploid (right) Festuca plants and referance plant (Vicia sativa) G1 peaks and the view of mitosis chrosomes of Festuca plants

genomlara sahip birden fazla türü ve onların hibritlerini içermesi yada Festuca' ların sahip olduğu yüksek heterojen yapı ile açıklanabilir. Yapılan sitolojik incelemelerde bu iki grupta yer alan bitkilerin $2=14$ kromozom sayısına sahip olduğu ve dolayısıyla diploid oldukları belirlenmiştir (Şekil 3). Yapılan taksonomik değerlendirmelerde bir popülasyon hariç (F-123) bu grup içerisinde yer alan tüm popülasyonlar $F$. valessiaca olarak teşhis edilmiştir. F-123 nolu popülasyon Vulpia myorus olarak teşhis edilmiştir. Üçüncü (grup C) ve dördüncü grupta (grup D) yer alan 27 popülasyonun ortalama çekirdek DNA içerikleri de bir birine oldukça yakın olup, 9.20 $\mathrm{pg} / 2 \mathrm{C}$ ile $9.60 \mathrm{pg} / 2 \mathrm{C}$ arasında değişmektedir. Yapılan sitolojik incelemelerde bu iki grupta yer alan bitkilerin $2 n=28$ kromozom sayısına sahip tetraploid bitkiler oldukları belirlenmiştir. Poliploidlerin diploid bitkilerden orijinlendiği göz önünde bulundurulduğunda poliploidlerinde yüksek bir heterojen yapıya sahip olması normal bir durumdur. Yapılan taksonomik değerlendirmelerde tetraploid popülasyonlar $F$. chalcophaea subsp. Chalcophaea olarak teşhis edilmiştir. Beş, altı, yedinci ve sekizinci (Grup E, F, G, H) gruplarda yer alan toplam 14 popülasyonun ortalama çekirdek DNA içerikleri de önceki gruplarda olduğu gibi bir birine oldukça yakın olup, $12.46 \mathrm{pg} / 2 \mathrm{C}$ ile $13.27 \mathrm{pg} / 2 \mathrm{C}$ arasında değişmektedir. Yapılan sitolojik incelemelerde bu gruplarda yer alan popülasyonların $2 n=42$ kromozom sayısına sahip hexaploid bitkiler oldukları belirlenmiştir. Yapılan taksonomik değerlendirmelerde hexaploid popülasyonlar $F$. heterophylla olarak teşhis edilmiştir.

Dokuzuncu grupta (grup I) yer alan 5 popülasyonun ortalama çekirdek DNA içerikleri $14.37 \mathrm{pg} / 2 \mathrm{C}$ ile $15.03 \mathrm{pg} / 2 \mathrm{C}$ arasında değişmektedir. Yapılan sitolojik incelemelerde bu grup içerisinde yer alan bitkilerin $2 n=56$ kromozoma sahip octaploid bitkiler oldukları belirlenmiştir (Şekil 3). Bu grupta yer alan 2 popülasyona ait bitkiler üzerinde teşhis yapılmaya çalışılmış ve F-6 nolu popülasyon $F$. heterophylla olarak teşhis edilirken $\mathrm{F}-51$ nolu popülasyon $F$. chalcophaea subsp. chalcophaea olarak teşhis edilmiştir. Yapılan bu çalışmada F-114 nolu popülasyonun $7.36 \mathrm{pg} / 2 \mathrm{C}$ ortalama çekirdek DNA içeriği ile festucalardan ayrıldığı dikkati çekmiş ve bu popülasyona ait bitkilerin yapılan taksonomik değerlendirmesinde bitkiler Poa pratensis olarak teşhis edilmiştir. Festuca popülasyonlarından 9 popülasyonun ise $(F-24,49,62,73,81,86,92$, $113,116)$ aslında farklı ploidy düzeyine sahip türleri hatta farklı ploidy düzeyine sahip bitkilerin melezlerini içerdikleri ve dolayısıyla karışık oldukları saptanmıştır.

\section{Sonuç}

Çalışmada elde edilen sonuçların daha önce yapılmış olan çalışmalar ile benzer olduğu gözlenmiştir. Samarda ve arkadaşları (2008), 101 Festuca taksonu ve 14 yakın akrabasının çekirdek DNA içeriklerini flow sitometri ile belirlemiş ve cinsin içerisinde $2 \mathrm{C}$ çekirdek DNA içeriğinin $3.88 \mathrm{pg}$ ( $F$. arvensis) ile $24.08 \mathrm{pg}(F$. gamisansii) arasında değiştiğini gözlemişlerdir. Ancak çalışmalarda kullanılan bitki materyallerinin aynı olmaması sebebiyle tam bir karşılaştırma yapmak mümkün olamamıştır. Yapılan çalışmada; flow sitometri yöntemiyle popülasyonların çekirdek DNA içerikleri belirlenmiş ve türlerin ploidy düzeyleri ile taksonomik teşhislerinde kullanılmıştır. Çalışmadan elde edilen sonuçlara göre doğal vegetasyonlardan toplanan buğdaygil yem bitkisi 
popülasyonlarının sıklıkla farklı tür ve ploidi araştırma yada ıslah programlarına dahil edilmeden önce muhakkak doğru bir şekilde teşhis edilerek ploidy düzeylerinin belirlenmesi gerektiği açıkça ortaya çıkmıştır. Ayrıca, flow sitometri yönteminin özellikle morfolojik olarak bir birine çok benzeyen ve doğada birlikte yetişen yem bitkilerinin teşhisi ile ploidy düzeylerinin belirlenmesinde son derece yararlı olduğu görülmüştür. Bu nedenle flow sitometrinin benzer çalışmalarda en güvenilir, ucuz, kolay ve hızlı bir metot olarak kullanılabileceği bir kez daha ortaya konmuştur.

\section{Teşekkür}

Bu çalışma TUBITAK tarafından 1130156 numaralı proje ile desteklenmiştir.

\section{Kaynaklar}

Bennett M.D. and Smith J.B., 1976. Nuclear DNA amounts in angiosperms. Phil. Trans. R. Soc. Lond. B., 274:227-276

Bennett M.D. and Leitch I.J., 1995. Nuclear DNA amounts in angiosperms. Ann. Bot., 76:113176

Brummer E.C., Cazcarro P.M. and Luth D., 1999. Ploidy determination of alfalfa germplasm accessions using flow cytometry. Crop Sci., 39:1202-1207

Davis P.H., 1985. Flora of Turkey and the East Aegean Islands. - Pp:.? in Davis PH (ed.), Flora of Turkey and the East Aegean Islands 9. - Edinburgh: Edinburgh University

Heslop-Harrison J.S., 1995. Flow cytometry and genome analysis. Probe, 5:14-17

Karp A., 1991. Cytological techniques. (Ed: K. Lindsey), Plant Tissue Culture Manual. Kluwer, Dordrecht, the Netherlands. P. C4:113
Lu K., Kaepler S.M., Vogel K.P., Arumuganathan K. and Lee D.J., 1998. Nuclear DNA content and chromosome numbers in switchgrass. Great Plains Research 8 (Fall 1998): 269-80

Ohri D., 1998. Genome size variation and plant systematics. Ann. Bot., 82 : 750-812

Pecinka A., Suchankova P., Lysak M.A., Travnicek B. and Dolezel J., 2006. Nuclear DNA content variation among Central European Koeleria taxa. Annals of Botany, 98:117-122

Rayburn A.L., Auger J.A., Benzinger E.A. and Hepburn A.G., 1989. Detection of intraspecific DNA content variation in Zea mays $L$. by flow cytometry. J. Exp. Bot., 40:1179-1183

Rees H. and Walter M.R., 1965. Nuclear DNA and the evolution of wheat. Heredity, 20:73-82

Smarda P., Bures P., Horova L., Foggi B. and Graziano R., 2008. Genome size and GC content evolution of festuca: ancestral expansion and subsequent reduction. Annals of Botany, 101: 421-433

Tuna M., Vogel K.P., Arumunagathan K. and Gill K.S., 2001. DNA contents and ploidy determination of bromegrass germplasm accessions by flow cytometer. Crop Science, 41:1629-1634

Tuna M., Deepak K.K., Shresta M.K., Arumuganathan K. and Golan-Goldhirsh A. 2004. Characterization of Dactylis polpulations collected from natural ranges of Thrace Region of Turkey based on ploidy and RAPD analysis. Euphytica, 135: 39-46

Tuna M., Vogel K.P. and Arumuganathan K., 2006. Cytogenetic and nuclear DNA conent characterization of diploid Bromus erectus and Bromus variegatus". Crop Science, 46: 637-641

Vogel P.K., Arumuganathan K. and Jensen K.B., 1999. Nuclear DNA content of perennial grasses of the Triticeae. Crop Sci., 39:661667 